УДК 811.111

DOI: https://doi.org/10.33989/2075-146x.2020.25.223211

\title{
VALENTYNA ISCHENKO
}

ORCID: 0000-0002-4812-0859

\section{YURI DZEKUN}

ORCID: 0000-0001-6342-7245

\section{OLENA KONONENKO}

ORCID: 0000-0002-8307-9302

Higher Educational Establishment "Poltava University of Economics and Trade"

\section{EFFECTIVE TEACHING STRATEGIES OF BUSINESS ENGLISH: EXPERIENCE OF POLTAVA UNIVERSITY OF ECONOMICS AND TRADE}

\begin{abstract}
The article deals with new approaches to teaching Business English in non-language institutions of higher education. The authors offer an example of the application of the strategy "Learning together", which involves the integrated study of special disciplines and foreign languages. This strategy was initiated by teachers in the United States and has proven its effectiveness. At Poltava University of Economics and Trade, teachers of the Department of Business Foreign Language have been using this approach to teaching for 20 years. During this period the courses "Language of Marketing", "Language of Management", "Language of International Economics", "Language of Human Resource Management", "Language of Information Systems in Management", "Language of Transnational Companies", "Language of Mathematics", "Language of Statistics", "Language of Informatics", "Language of Computer Science" were developed and introduced.

Experience has shown that the application of this strategy deepens the knowledge of students and special disciplines, helps to master the terminology, as well as increases the motivation of students to study both professional subjects and foreign languages.
\end{abstract}

Key words: Learning Communities strategy, teaching materials, case study method, presentation, business correspondence

Statement of the problem in general and an indication of its connection with important scientific or practical tasks. Business English is basically a part of English language which is related to international activities of companies. It is important to know how to teach Business English if you are teaching or going to teach in a business school. Business English is considered to be a specification of English language learning and teaching. Today English has become the global language. Trading and business is done all around the world and the language which is used for communication is no other than English itself.

Nowadays, as the business and corporate sector is booming, everybody wants to get into the corporate sector in any manner. For this, everybody wants to learn Business English and thus there is an increment in the demand for business English teachers. If you want to make a career in this field then you have to know the proper way of teaching Business English. In this paper we are going to share our experience and we hope it will help you in this concern.

In Poltava University of Economics and Trade several teaching strategies are used to make the process of teaching Business English more effective and efficient. One of them is Learning Communities strategy.

Analysis of the most important publications in which the solution of the researched problem is initiated and on which the author relies. Learning Communities mean classes that are linked during an academic term, often around an interdisciplinary theme, and enrol a common cohort of students (Davies, Pearse, 2000). The goal of Learning Communities (LCs) is to build community among students, between students and their teachers, and among faculty members and disciplines (Wood, 2007). The three general types of LCs structures (Golde, Pribbenow, 2000, p. 28) are as follows:

1) Student Cohorts/Integrative. Seminar LCs can be structured as programs in which a small cohort of students enrolls in larger classes that faculty do not coordinate. In this instance, intellectual connections and community-building often take place in an additional integrative seminar (Buysse, Sparkman, Wesley, 2003).

2) Linked Courses/Course Clusters. LCs may involve two or more classes linked thematically or by content which a cohort of students takes together. In this instance, the faculty plan the program collaboratively (Mitchell, Sackney, 2005).

3) Coordinated Study. LCs may involve coursework that faculty members team teach. The course work is embedded in an integrated program of study (Mitchell, Sackney, 2005).

Distinguishing still unresolved aspects of the scientific problem, which and devoted to this article. In Poltava University of Economics and Trade (PUET) we use Linked Courses which we define as Learning Communities that involve two or more classes linked thematically or by content which a cohort of students takes together. In this instance, the professors plan the program collaboratively.

Ten courses based on learning through content approach have been developed in the time period of $2000-2020$. We call them "Language of Marketing", "Language of Management", "Language of International Economics", "Language of Human Resource Management", "Language of Information Systems in Management", "Language of Transnational Companies", 
"Language of Mathematics", "Language of Statistics", "Language of Informatics", "Language of Computer Science”.

Formulation of the purpose and tasks of the article. We believe that Learning Communities strategy offers an array of opportunities both for teachers and students. The approach utilizes case studies with different types of activities problem solving, simulation, discussion, written reflection, point of view presentation, mini-research, etc. It helps explore issues in cross-cultural communication in the business context and encourages them think critically to find solutions to business problems thus developing communication skills and skills they need to succeed in an increasingly diverse and technologically enhanced workplace of today. So, the purpose of this paper is to discuss the benefits of implementing the LCs strategy into the process of training future specialists for Business sector. The tasks of the article are: 1) to define the concept "Learning communities", 2) to share the experience of the teaching stuff of Poltava University of Economics and trade, 3) to discuss the steps of language teaching, 4) to highlight the types of tasks for ESL classes, 5) to show how the strategy can motivate both students and professors.

Statement of the main material with a full justification of the obtained scientific results. Faculty members involved in LCs that facilitate cross-faculty collaboration are expanding their repertoire of teaching approaches, continually revising their course content, and acquiring new scholarly interests. LCs faculty members are also building mentoring relationships with each other and are more frequently engaging with beginning students and general education offerings.

Sometimes textbook exercises can be boring. That is why many Business English teachers find it useful to give problem solving activities. The books that we use for LCs offer activities which are centered on solving problems and making decisions (Archer, 1997; Cateora, 1996; Kotler, Armstrong, 2001). Some activities you can give are: make a report on how to market a new product; write the procedure of planning a budget; write the procedure of choosing a new employee. You should offer different topics for discussion. One could get bored of talking on the same topic every time. You can use these topics for discussions: business etiquette in a multinational company; brain drainage; working in a different place or culture.

Teaching Business English to adult students requires increasingly effective teaching materials (Andrea B. Geffer, 2004). Case studies used in a language class give opportunities to extensively practice speaking and writing skills based on materials that are challenging and relevant for business students.

One of the possible methodologies of doing cases in language teaching includes the following steps:

reading the case,

discussing the situation in the company,

analyzing and discussing the quantitative data,

filling up information gaps and putting forward hypotheses,

discussing weaknesses and threats,

presenting company goals,

presenting alternative solutions of the problem,

discussing the solutions, comparing them and choosing the best one,

presenting plan $\mathrm{B}$,

preparing an action plan, assigning tasks and setting the deadlines.

The first step includes reading, the other ones develop speaking skills - students present their opinions, criticize, present their point and negotiate. Usually they work in teams and each team competes with other teams trying to offer the best solution to the problem. Students like doing case studies because then they are the decision-makers. They are not told what to say. They are the managers and the teacher is just an observer, mediator and facilitator.

The case study method also provides an opportunity to develop writing competence. For instance one group of students may be asked to take the minutes of the meeting called to solve the problem or to write an agenda of the meeting. When the discussion at the meeting finishes and the final decision is taken, all students are requested to use the information in a written form. It may be a letter, a memorandum, a list of points, a mind map, an action plan, a report, an e-mail or a note - any kind of business writing which best suits the situation. To do that, they need instruction from their teacher on the layout, style and appropriate tone.

The case study method gives teachers a lot of flexibility in assigning tasks, roles and functions. The teacher should not blindly follow the instructions in the teacher's book. Helpful as they are, they are not the only directions in using a particular case. Teachers should be encouraged to experiment and use cases as input materials that are alive in class - modified, changed and exploited in various ways.

One more important skill for students majoring in Business is making a presentation. You should involve works on business presentations in your teaching method. It will make it more effective. It is very useful to practice making and giving presentations in English for the students. You should teach useful phrases to your students for introduction of a topi Ic, for shifting from one idea to the next and lastly for the conclusion of a presentation.

Encourage students to use support material and visual aids. The bare minimum would be a whiteboard or flipchart. If you have a multimedia projector, it is so much better. Remind them not to overcrowd their graphics (one graphic - one point; two points two graphics). And don't forget the value of reality - actual products or samples that the presenter brings in from outside.

Almost all professionals who use English for business will need to write letters, memos, invitations and short reports. Business writing is an important skill especially to those who work in an office. It establishes formality and civility among employees and employers, as well as those that are outside the work place. It also creates a professional atmosphere and shifts the environment toward work rather than personal life. There are various kinds of business writing, but here are some guidelines which are followed by ESP professors in PUET when teaching communications that can be applied in various situations:

Explain the structure of a business letter. Structure is different from the format. Format applies to the aesthetic part of the letter, while structure refers to the content itself. Business writing is usually straightforward and generally includes the main 
gist of the piece in the first few paragraphs (Andrea B. Geffer, 2004, p. 46). Business writing also includes situational examples in the body of writing and steps to follow towards the end.

Make your students familiar with the tone used in business communication. Teaching business communication is like teaching a second language. You will increase fluency of your students the more you make them to read, the more they used it and the more you surround them with people who are using it. Get insights in the workplace by paying attention to how people communicate.

Teach how to format the piece of writing depending on purpose and recipient. Appropriateness is not limited to content, because format is also important however superficial. Formatting a piece of writing allows it to meet certain standards, which is essential in establishing formality and structure. Include dates, titles, recipients, applicable addresses and other important information. Some also gives a piece more visual appeal by incorporating different elements such as pictures, diagrams and charts. A word processor is needed to format the letter easier, since programs include wizards that guide you through the process. You can also adjust document and printer settings to achieve the format you want. Use examples of business documents such as memos, reports and correspondence and analyze how they are written. In order to become an expert in business writing, it is essential to be exposed to different kinds of work that have been published before. Analyzing certain documents and understanding the purpose of each piece also allow one to be more critical of one's work.

Results of the research and prospects for further development of this thematic area. In general the issue how to teach Business English is a challenge all teachers face. Since every classroom consists of a wide array of students, each student brings with them different student learning styles, different interests, and different life experiences that make each classroom unique and special. That is why a particularly effective general approach for the teacher is to see this kind of teaching as both a teaching and a learning process for the teacher, where a great deal of interesting information about a wide range of business processes can be acquired. These are some points that can be used to make teaching skills better. Business English is a very important part of today's society. It must be taught in its correct and applicable form.

\section{References}

Andrea B. Geffer. Business English: a complete guide to developing an effective business writing style / Andrea B. Geffer Barron's Educational Series, 2004. - 368 p.

Archer J. The Fourth Estate / J. Archer - Glasgow: Caledonian International Book Manufacturing Ltd, 1997. - 551 p.

Cateora P.R. International Marketing / P.R. Cateora - Boston, Massachusets: Irwin / McGrow-Hill, 1996. - 772 p.

Buysse, V., Sparkman, K. L., Wesley, P. W. Communities of practice: Connecting what we know with what we do. Exceptional children, 69(3). - 2003. - p. 263-277.

Davies, Paul, Pearse, Eric. Success In English Teaching, Oxford Handbooks for Language Teachers / Davies, Paul, Pearse, Eric Oxford University Press, 2000. - 276 p.

Easton, L. B. The 5 Habits of Effective PLCs. Journal of Staff Development, 36(6). -2015. - p. 24-34.

Golde, C. M., Pribbenow D. A. Understanding Faculty Involvement in Residential Learning Communities / Golde, C. M., D. A. Pribbenow // Journal of College Student Development. - 2000. - № 41(1). - p. 27-40.

Kotler P., Armstrong G. Principles of Marketing / P.Kotler, G. Armstrong - New Jersey: Prentice Hall, 2001. - 523 p.

Mitchell, C., Sackney, L. Building capacity for a learning community. Canadian Journal of Educational Administration and Policy, 19. - 2005. - p. 394-398.

Wood, D. R. Professional learning communities: Teachers, knowledge, and knowing. Theory into Practice, 46(4). - 2007. - p. 281290

\section{ІЩЕНКО В., ДЗЕКУН Ю., КОНОНЕНКО О.}

Вищий навчальний заклад Укоопспілки «Полтавський університет економіки і торгівлі», Украъна

\section{ЕФЕКТИВНІ СТРАТЕГІї ВИКЛАДАННЯ ДІЛОВОЇ АНГЛІЙСЬКОЇ МОВИ: ДОСВІД ПОЛТАВСЬКОГО УНІВЕРСИТЕТУ ЕКОНОМІКИ І ТОРГІВЛІ}

У статті розглядаються нові підходи до викладання ділової англійської мови у немовних закладах вищої освіти. Автори пропонують приклад застосування стратегії «Вчимося разом», яка передбачає інтегроване вивчення спеціальних дисциплін та іноземної мови. Така стратегія була започаткована викладачами в США та довела свою ефективність. У Полтавському університеті економіки і торгівлі викладачі кафедри ділової іноземної мови протягом 20 років використовують такий підхід до викладання. Протягом цього періоду були розроблені курси «Мова маркетингу», «Мова управління», «Мова міжнародної економіки», «Мова управління людськими ресурсами», «Мова інформаційних систем в менеджменті», «Мова транснаціональних компаній», «Мова математики», «Мова статистики», «Мова інформатики», «Мова комп'ютерних наук».

Викладання ділової англійської мови для дорослих студентів вимагає дедалі ефективніших навчальних матеріалів. Тематичні дослідження, що використовуються на занятті з іноземної мови, дають можливість широко практикувати навички говоріння та письма на основі матеріалів, що є складними та актуальними для студентів, що вивчають бізнес. Одна з можливих методологій ведення кейсів при викладанні мови включає такі етапи: 1) 
читання кейсу, 2) обговорення ситуації в компанії, 3) аналіз та обговорення кількісних даних, 4) заповнення інформаційних прогалин та висунення гіпотез ,5) обговорення слабких сторін та загроз, 6) представлення цілей компанії, 7) представлення альтернативних рішень проблеми, 8) обговорення рішень, їх порівняння та вибір найкращого, 9) представлення плану В, 10) підготовка плану дій, розподіл завдань та встановлення термінів. Перший крок включає читання, інші розвивають мовленнєві навички - студенти викладають свої думки, критикують, висловлюють свою думку та ведуть переговори. Досвід показав, що застосування цієї стратегії поглиблює знання студентів та спеціальних дисциплін, сприяє засвоєнню термінології, а також підвищує мотивацію студентів до вивчення як фахових предметів, так і іноземних мов.

Ключові слова: стратегія «Вчимося разом», навчальні матеріали, метод кейсів, презентація, ділова кореспонденція

Стаття надійшла до редакції 11.07.2020 р.

УДК 378.091.39:004:316.77

DOI: https://doi.org/10.33989/2075-146x.2020.25.223215

КАРІНА КОВІНЬКО

ORCID: 0000-0002-4082-9660

Харківський національний університет імені В.Н. Каразіна

\section{ОГЛЯД ТИПІВ ЗМІШАНОГО НАВЧАННЯ (BLENDED LEARNING) В СУЧАСНОМУ ОСВІТНЬОМУ ПРОСТОРІ В МЕЖАХ КЛАСИЧНОГО УНІВЕРСИТЕТУ}

Розглядається змішане навчання та його типи в межах класичного університету. Вирізняються та обгрунтовуються найбільш дієві типи змішаного навчання для сучасного освітнього простору Аналізуються переваги та недоліки змішаного навчання. Робиться висновок, що запровадження змішаного навчання в університеті повинно призвести до підвищення якості університетської освіти загалом

Ключові слова: викладач, змішане навчання, здобувачі освіти, студенти, тип навчання, метод навчання

Постановка проблеми. Стрімкий розвиток технологій та виклики ХХІ століття дедалі частіше піднімає питання пошуку нових підходів в освіті та переходу до онлайн типів навчання. Одним з успішних та досить дієвих є змішане навчання.

Blended Learning, або змішане навчання,- це сучасна концепція в освіті, в межах якої здобувачі освіти отримують знання як самостійно онлайн, так і на заняттях з викладачем. Такий підхід в освітньому просторі дає змогу контролювати час, темп та способи вивчення матеріалу. Змішана освіта дозволяю поєднувати традиційні методи викладання 3 актуальними сучасними технологіями. Фактично концепція не $\epsilon$ новою, a термін Blended Learning 3'явився ще у XX столітті. Але широко використовувати цей метод почали 3 лише на початку XXI століття.

Аналіз найвагоміших публікацій. Останнім часом дуже багато зарубіжних та вітчизняних дослідників піднімали питання змішаного навчання в вишах. Серед зарубіжних дослідників хотілося б визначити Кукулска-Хулме, А., Беірне, Е., Цоноле, Г., Цостелло, Е., Цоугхлан, Т., Фергусон, Р., ФітзГералд, Е., Гавед, М., Херодотоу, Ц., Холмес, В., Мац Лочлаінн, Ц., Ніц Гиолла Мхичі́л, М., Ріентіес, Б., Саргент, Й., Сцанлон, Е., Шарплес, М., Вхителоцк, Д. Серед вітчизняних цю проблему досліджували Желнова Є. , Кривонос О., Кухаренко В. , Нікітіна М. , Стрюк А. , Триус Ю. , Чередніченко Г. , Шапран Л. та інших.

За визначенням вітчизняних авторів А. Стрюка, Ю. Триуса, В. Кухаренка, змішане навчання - це цілеспрямований процес здобування знань, набуття вмінь та навичок в умовах інтеграції аудиторної та позааудиторної навчальної діяльності суб'єктів освітнього процесу на основі впровадження і взаємного доповнення технологій традиційного, електронного, дистанційного та мобільного навчання за наявності самоконтролю студента за часом, місцем, маршрутами та темпом навчання (Кухаренко, Березенська, Бугайчук та ін., 2016). До типових визначень змішаного навчання також відноситься: змішане навчання - це метод який пов'язує в собі традиційне навчання «обличчям до обличчя» 3 деяким елементами дистанційного навчання (Логінова, 2015).

Цей вид навчання вирішує такі завдання (Кондакова, 2013): розширює освітні можливості студентів за рахунок доступності та гнучкості, урахування їхніх індивідуальних освітніх потреб, а також темпу й ритму оволодіння навчальним матеріалом; стимулює формування суб'єктної позиції студента: підвищення його мотивації, самостійності, соціальної активності, рефлексії та самоаналізу і, як наслідок, підвищує ефективність освітнього процесу в цілому; трансформує стиль педагога: забезпечує перехід від трансляції знань до інтерактивної взаємодії зі студентом, що сприяє формуванню процесу конструювання власних знань; персоналізує освітній процес: студент самостійно визначає свої навчальні цілі, способи їх досягнення, ураховуючи власні освітні потреби, інтереси та здібності; викладач у цій ситуації є помічником студента. 